\title{
Cardiovascular Diseases - A Cause to Worry in Indonesia
}

\section{Suyanto, Normalina Sandora, Laode Burhanuddin, Miftah Azrin*}

* Fakultas Kedokteran Universitas Riau

\begin{abstract}
Cardiovascular diseases (CVDs), caused by disorders of the heart and blood vessels, have been associated with changes in peoples' lifestyles due to the improving economy. In Indonesia, the prevalence CVDs tend to increase recently following the improving of national economic development. In controlling CVD, Indonesian Government particularly Ministry of Health have launched CVD control programme including primary, secondary, and tertiary prevention. However, this policy should be disseminated to people. Thus, the general public is more health conscious.
\end{abstract}

Key Word : Cardiovascular, Diseases, Prevention

\section{Abstrak}

Penyakit jantung (CVDs), disebabkan oleh gangguan jantung dan pembuluh darah, telah dikaitkan dengan perubahan gaya hidup masyarakat karena ekonomi membaik. Di Indonesia, prevalensi CVDs cenderung meningkat baru-baru mengikuti meningkatkan pembangunan ekonomi nasional. Dalam mengendalikan CVD, Pemerintah Indonesia khususnya Departemen Kesehatan telah meluncurkan program pengendalian CVD termasuk pencegahan primer, sekunder, dan tersier. Namun, kebijakan ini harus disebarluaskan kepada masyarakat. Dengan demikian, masyarakat umum sadar untuk memperhatikan kesehatan.

Kata Kunci : Penyakit Cardiovaskular, Diseases, Pencegahan

\section{Introduction}

In Indonesia cardiovascular diseases (CVDs) are becoming a major cause of mortality and morbidity (Ministry of Health, 2006). They have been associated with changes in peoples' lifestyles due to the improving economy. These diseases are caused by disorders of the heart and blood vessels. Usually these diseases may manifest themselves as heart attacks, stroke, hypertension, peripheral artery disease, rheumatic heart disease, congenital heart disease and heart failure.

Heart attacks and strokes are mainly caused by a blockage in the blood vessels that prevents the flow of blood to the heart and brain. Usually it is due to the build-up of fats in the inner walls of the blood vessels-causing them to become narrower and less flexible (Mayo Clinic Staff, 2003).
Globally, cardiovascular diseases are the number one cause of death. In 2005, an estimated 17.5 million people died from cardiovascular diseases. About $80 \%$ of these deaths occurred in low and middleincome countries. WHO estimates that unless some serious action is taken, about 20 million people will die by 2015 . More than $60 \%$ of seemingly healthy public service employees are at risk of cardiovascular disease due to plasma cholesterol and related lipid levels (Okot, 2006).

The main causes on CVDs are obesity, smoking, lack of exercise or lazy lifestyles and eating unhealthy/fatty foods. Signs and symptoms of a heart attack include pain or discomfort in the chest, arms, legs, left shoulder, jaw, elbows and back. Difficulty or shortness of breath, feeling sick and vomiting, dizziness, faintness and light 
headedness, breaking into a sweat and becoming pale. The signs of a stroke may include sudden weakness and or numbness of the face, arm, leg usually occurring on one side of the body. Other signs include confusion, difficulty walking, loss of balance, severe headache, fainting and unconsciousness. However it should also be noted that sometimes strokes and heart attacks may occur without any warning signs (WHO, 2008).

\section{How can one prevent or avoid cardiovascular diseases?}

1. Exercising regularly at least 30 minutes a day

2. Avoid smoking including second hand inhaling of smoke

3. Have your blood pressure checked regularly especially if you are diabetic

4. Eating healthy - lots of fruits, vegetables, reducing salt intake to about 1 tea spoon daily, reducing consumption of oily foods especially fast foods

Various medical innovations have been developed to help curb CVDs. These include; pace makers, prosthetic valves and patches for closing holes in the heart. However most Indonesians can not afford any of the above (Indonesia's Central Burrow of Statistik, 2004). Operations like heart transplants, coronary bypass, valve repair and replacement are extremely costly. The World Health Organisation (WHO) suggests a comprehensive and integrated approach to prevent and control CVDs. Interventions of CVDs could be done at three main levels; Primary, Secondary and Tertiary (WHO, 2007).

\section{Primary Prevention}

Targets the general public and individuals who may not already have CVDs :

1. Advocacy seminars could be held with political leaders, policy makers, health officials, district officials and members of the general public to raise awareness on CVDs. Including making better city plans were there are green areas designated to exercising and other sporting events.

2. Put bans on smoking in public places and cigarette advertising. Increase taxes on cigarette importation.

3. Health education awareness campaigns could be held in schools, and out-of-school communities to raise awareness on CVDs.

4. Providing children in school with better healthier meals

5. Media campaigns could be conducted on radio, $\mathrm{TV}$, newspapers, billboards and posters on CVDs. Encouraging healthy lifestyles

These interventions could be conducted by Ministry of Health (MOH), Ministry of Education (MOE), Non Governmental Organisations (NGOs), Faith Based Organisations (FBOs), Community Based Organisations (CBOs), health professionals, political figures, public celebrities and sports clubs like 'hashers' (A big group of health conscious people that jog and do other sporting activities in a bid to keep fit) weekly. Oppossers of this intervention may include cigarette companies, exporters, importers and smokers.

\section{Secondary prevention}

Targets those with CVD and are at a high risk of reoccurrence of for example a stroke or heart attack. These people are encouraged to :

1. Eat healthy diets (lots of fruits, vegetables, less fatty foods, lots of fibre.

2. Reduce or stop alcohol consumption

3. Exercise regularly

4. Go for regular blood pressure check-ups 
5. Seek immediate treatment and medical attention in case of suspected signs and symptoms of 'an attack'.

Interventions could be conducted by $\mathrm{MOH}, \mathrm{MOE}$, health professionals, gym and fitness instructors, and concerned members of the public.

\section{Tertiary prevention}

This may include:

1. Scaling up of emergency services at hospitals and clinics

2. Making CVDs drugs and treatment available and affordable.

3. Training health workers on what treatment to offer CVDs patients.

This could be done by health professionals, expatriates and $\mathrm{MOH}$. Opposers may include Ministry of Finance. In our opinion, oppossers should be lobbied, through advocacy campaigns, meetings, workshops and seminars. The media should also be used as a tool for advertising and enticing oppossers to 'join the health movement'.

\section{Conclusion}

CVDs should not be ignored because statistics show that they are on an increase in Indonesia especially among 'well-to-do' citizens. The general public needs to be more health conscious by eating healthy diets, exercising regularly, avoiding smoking and inhaling cigarette smoke, and to seek prompt medical attention in case of any signs and symptoms of CVDs mentioned in this article.

\section{References}

Bimenya GS, Okot JK et al, 2006. Plasma Cholesterol and related Lipid levels of seemingly healthy public service employees in Kampala, Uganda. Available at: http://www.pubmedcentral.nih.govarticlerender.fcgi?tool=pubmed\&pubmedi $\underline{\mathrm{d}=17140334}$ Accessed on June 122010

Indonesia's Central Burrow of Statistic (2004) National and Welfare Survey, Jakarta

Mayo Clinic staff (2003). Cardiovascular disease 101: Understanding heart and blood vessel conditions.

Ministry of Health (2006). Indonesia Health Profile 2005. Jakarta

World Health Organization 2008, Fact sheet about cardiovascular diseases. World Health Organization: Geneva, Switzerland World Health Organization, 2007. Prevention of cardiovascular disease. Pocket guidelines for assessment and management of cardiovascular risk. World Health Organization: Geneva, Switzerland. 